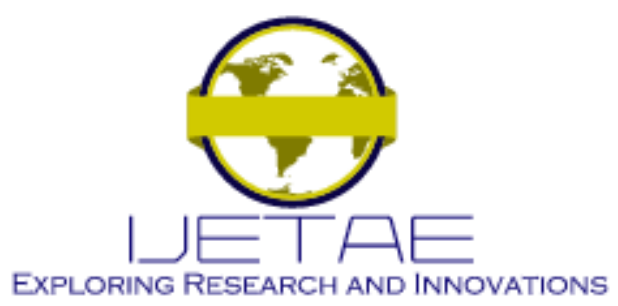

International Journal of Emerging Technology and Advanced Engineering

Website: www.ijetae.com (E-ISSN 2250-2459, Scopus Indexed, ISO 9001:2008 Certified Journal, Volume 11, Issue 12, December 2021)

\title{
The Role of E-Customer Relationship Management in Driving E-Commerce Performance
}

\author{
Rynaldi Lesmana Syahputra ${ }^{1}$, Wijaya Mulyana Wangsajaya ${ }^{2}$, Khelvin Wijaya ${ }^{3}$, Noerlina ${ }^{4}$, Tirta Nugraha Mursitama ${ }^{5}$ \\ 1,2,3,4 Information Systems Department, School of Information Systems, Bina Nusantara University, Jakarta, Indonesia 11480 \\ ${ }^{5}$ International Relations Department, Faculty of Humanities, Bina Nusantara University, Jakarta, Indonesia 11480
}

\begin{abstract}
This research aims to determine the effect of ECRM on repurchase intention directly or through the mediation of customer satisfaction and customer trust. This survey was conducted on E-Commerce users. This study uses a quantitative approach and uses as many as 350 respondents. In analyzing the data, the Structural Equation Model (SEM) was used using the SmartPLS application. The results of this study ECRM has a positive influence on repurchase intention directly and indirectly through the mediation of customer satisfaction and customer trust. This research is aimed at e-commerce users with the trust and satisfaction of users to repurchase a product or service in an E-commerce.
\end{abstract}

Keywords-- ECRM, E-Commerce, Repurchase Intention, Customer Satisfaction, Customer Trust

\section{INTRODUCTION}

In this era of rapidly developing technology, the effects of Globalization indirectly create a competition between companies' marketing strategies to increase the numbers of their customers. In today's digital age, marketing strategy is influenced by two factors: product innovation and methods to gain customers from other companies by optimizing more competent customers. According to [1], Companies should always connect and be familiar with their customers by implementing IT. The role of the Customer today exceeds that of the producer's, and the Customer nowadays is now having a more critical influence a brand Co-Ownership and the success of a company. In the past, the main task of Brand management was to maintain the image and Company's relationship with its Customer. Still, nowadays, customer service serves the producer and co-owner of the brand. This strategy focuses on gaining the Customer's loyalty and establishing relationships between customers, producers, and co-owners. The Company could also increase its Customer's engagement level by making them brand ambassadors [2].
Customer engagement is the key to creating customer satisfaction in this modern age and Electronic Customer Relationship Management (E-CRM) could help companies maintain and improve their engagement with customers. E-CRM is a web-based CRM that allows companies to interact and strengthen their relationship with customers. According to [3], E-CRM is an application system that connects customer relationships, business functions, and audiences. It focuses on maintaining and building long-term relationships between companies and customers to gain, retain, and extend their influence to broader customers [4]. Customer relationship managers are essential in E-Commerce for a number of reasons. First, building a relationship with customers is crucial to maintaining revenue, profits, and market share in today's market due to the rise of online marketplaces and the increasing through of competitors. Second, satisfied customers could create a free advertisement by promoting the product through social media. Lastly, customer relationships could make the Company more profitable through cross-selling, which would increase the Customer's desire to repurchase [5].

With the rise of CRM practice on the market, companies should have a knowledge on how to encourage the customers to keep buying the products. Customer Trust is one of the most critical factors in CRM, which means customers would trust a company with good customer relationship management. A good CRM would influence Consumer Behavior which would encourage a Repurchase intention from the Customer [6]. It would also pique an interest in another product from the Company. An E-Commerce with good customer service would create customer satisfaction and encourage the customers to keep buying the product from an E-Commerce. This can be proven by the theory that shows repurchase intention is motivated by a sense of interest and economic factors [7]. 


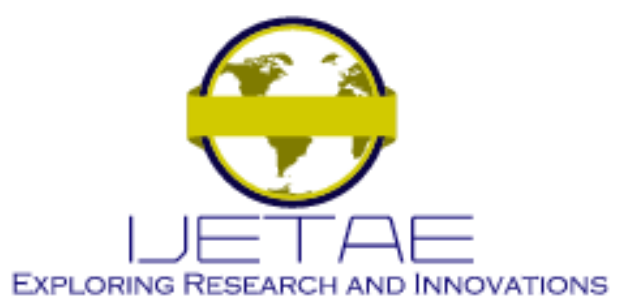

International Journal of Emerging Technology and Advanced Engineering

Website: www.ijetae.com (E-ISSN 2250-2459, Scopus Indexed, ISO 9001:2008 Certified Journal, Volume 11, Issue 12, December 2021)

It proves that Customer's desire to pay for a product is determined by both the product's quality and the quality of customer service.

\section{RESEARCH MethodS}

This research will use the quantitative data collection method, which analyze data in the form of numbers or nominal. Quantitative research is a data collection method that focuses on analyzing numerical data with an objective nature, intercorrelated variables, and identifying variables that can be measured [8]. The type of data used in this research is prime data. The data collection activity would be conducted through several methods like library research and distributing questionnaires. The questions from the questionnaire would be the result of the operationalization of translated variables from previous research to measure the relationship between variables using the Likert scale. This questionnaire was distributed from March 2021 to June 2021 using Google Forms through social media such as WhatsApp, Line, and Twitter.

The data analysis method used in this research is the descriptive analysis method. Descriptive analysis is a method that analyze the generalization of the research's results based on a sample [9]. The researchers will test the validity and reliability of the data. Then, the method would move to the Structural Equation Modeling (SEM) phase to find out the level of influence that the variables have on the tested variables.

\section{RESULTS AND DisCUSSION}

The hypotheses that would be tested in this study are:

- Does E-CRM affect Customer Satisfaction?

- Does E-CRM affect Customer Trust?

- Does E-CRM affect Repurchase Intention?

- Does Customer Satisfaction affect Repurchase Intention?

- Does Customer Trust affect Repurchase Intention?

- Does E-CRM affect Repurchase Intention through Customer Trust mediation?

- Does E-CRM affect Repurchase Intention through Customer Satisfaction mediation?

\subsection{Descriptive Statistical Analysis.}

The purpose of statistical analysis in this research is to determine the profile of respondents in terms of age, gender, university, semester, video conferencing application usage, and the frequency on how often the respondent use the application. There are 350 respondents that have met the criteria
TABLE 1.

Respondent's demographic

\begin{tabular}{|l|l|l|l|}
\hline \multicolumn{2}{|l|}{ Classification } & Frequency & Percentage \\
\hline \multirow{2}{*}{ Sex } & Men & 288 & $82.3 \%$ \\
\cline { 2 - 4 } & Women & 62 & $17.7 \% \%$ \\
\hline \multirow{2}{*}{ Age } & $\begin{array}{l}<15 \text { Years } \\
\text { old }\end{array}$ & 96 & $27,4 \%$ \\
\cline { 2 - 4 } & $15-30$ & 234 & $68 \%$ \\
\cline { 2 - 4 } & $\begin{array}{l}>30 \text { Years } \\
\text { old }\end{array}$ & 14 & $4 \%$ \\
\hline \multirow{2}{*}{ E-commerce } & Shopee & 240 & $68.6 \% \%$ \\
\hline \multirow{2}{*}{} & Tokopedia & 168 & $48 \% \%$ \\
\hline & Lazada & 63 & $18 \% \%$ \\
\hline Total & Bukalapak & 31 & $8.9 \% \%$ \\
\hline
\end{tabular}

3.2. Validity and Reliability Test.

After obtaining the data, researcher conducts a validity test to ensure that the data is valid. This validity test uses a sample of 350 respondents with a significance level of 5\% (0.05). A validity test is conducted to obtain the answers that will explain the dimensions that are being studied. This research will use two validity test methods, namely convergent validity, and discriminant validity. Convergent validity occurs when all the data in the measurement model has a high static value. Convergent validity can be calculated based on the Average Variance Extracted (AVE) for all data. The value of an AVE must be higher than 0.5 for the data to be valid and all data below this value would invalidate the convergent validity [10]. The first stage of the Smart PLS application would results in the Outer factor. The outer factor is the value generated by the indicator to measure a variable which would determine the validity of an indicator after obtaining the data. This measurement uses the value limit that has been used by previous researchers, which is 0.7 . If the variable value is less than 0.7 , it would mean that the indicator is invalid and will be removed from the indicator list until the outer factor touches the value limit of 0.7 and above [11]. After that, researcher will conduct an AVE test to find the Discriminant Validity Measurement, which would determine if one construct is different or the same as other constructs [11]. 


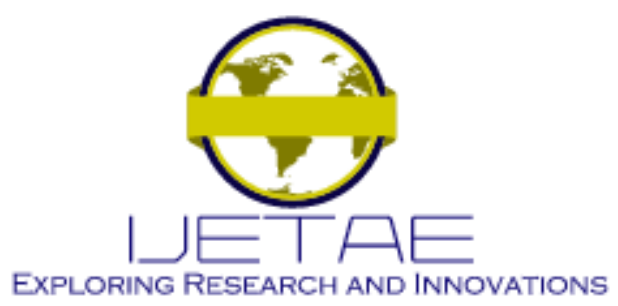

International Journal of Emerging Technology and Advanced Engineering

Website: www.ijetae.com (E-ISSN 2250-2459, Scopus Indexed, ISO 9001:2008 Certified Journal, Volume 11, Issue 12, December 2021)

SmartPLS application performs a Cross-Loadings on the first tests. Cross loading is conducted to check a discriminant validity other than the above criteria. If an indicator has a higher correlation with other latent variables than its latent variables, the researcher must reconsider the model's construct. After the data is acquired, the researchers could determine which indicators are valid and invalid. The second stage of Smart PLS Application is the Fornell-Larcker criterion. The Fornell-Larcker criterion is the second approach to assess the discriminant validity. This phase compares the square root of the AVE value with the correlation between the latent variables. In particular, the square root of each AVE construct must be higher than the highest correlation between the other constructs [11]. The data in this study is reliable since the Cronbach's Alpha value has exceeded the criteria, which is more than equal to 0.7 .

\subsection{Hypothetical Test.}

Hypothesis test that refers to the relationship between variables in this research uses $\mathrm{T}$ statistics and $\mathrm{P}$-value, which is the basis for researchers to determine how significant the relationship between exogenous and endogenous latent variables is. Researchers used a significance level of $5 \%$ since this research uses primary data. Thus, the data does not require a high level of accuracy to be analyzed. The results in the study are estimated to be significant at $5 \%$ alpha if the $\mathrm{T}$ statistic value is $>1.96$ and the $\mathrm{P}$-value is $<0.05$. Then the hypothesis can be accepted [11].

TABLE 2.

Hypothetical Test result

\begin{tabular}{|c|c|c|c|c|}
\hline $\begin{array}{c}\text { NO } \\
\text {. }\end{array}$ & $\begin{array}{c}\text { Original } \\
\text { sample }\end{array}$ & t-statistic & p-value & Results \\
\hline H1 & 0.669 & 16.743 & 0.000 & Accepted \\
\hline H2 & 0.654 & 15.945 & 0.000 & Accepted \\
\hline H3 & 0.204 & 2.807 & 0.005 & Accepted \\
\hline H4 & 0.290 & 3.433 & 0.001 & Accepted \\
\hline H5 & 0.219 & 2.692 & 0.007 & Accepted \\
\hline H6 & 0.194 & 3.364 & 0.001 & Accepted \\
\hline H7 & 0.143 & 2.573 & 0.010 & Accepted \\
\hline
\end{tabular}

Table 2 above states that:

- ECRM has a significant effect on customer satisfaction,

- ECRM has a significant and significant effect on customer trust.

- ECRM has a significant effect on repurchase intention,

- Customer satisfaction has a significant effect on repurchase intention,

- Customer trust has a significant effect on repurchase intention,

- ECRM has a significant influence on repurchase intention through customer satisfaction mediation,

- ECRM has a significant influence on repurchase intention through customer trust.

\subsection{Discussion on the Hypothesis}

H1: ECRM has a positive influence on Customer Satisfaction. The first Hypothesis states that ECRM has a positive influence on Customer Satisfaction. The data shows that the value of the parameter coefficient in the original sample between the ECRM variable and customer satisfaction was 0.669. this Hypothesis is also supported by significant testing on the $\mathrm{t}$ statistic and $\mathrm{p}$-value. The obtained $\mathrm{T}$ statistic is 16,743 ( $\mathrm{T}$ statistic > 1.96) and the obtained p-value is 0.000 (p-value $<0.05$ ). It can be concluded from the acquired data that $\mathrm{H} 1$ is accepted, and ECRM has a positive influence on Customer Satisfaction.

H2: ECRM has a positive effect on Customer Trust. The second Hypothesis states that ECRM has a positive influence on customer trust. The parameter coefficient value in the original sample between ECRM and customer trust is 0.654 . This Hypothesis is also supported by significant testing on the $t$ statistic and $p$-value. The obtained $t$ statistic is 15,945 (t statistic > 1.96) and the obtained p-value is 0.000 (p-value $<0.05$ ). It can be concluded from the acquired data that $\mathrm{H} 2$ is accepted and ECRM has a positive influence on Customer Trust

H3: ECRM has a positive effect on repurchase intention. The third Hypothesis states that ECRM has a positive influence on repurchase intention. The parameter coefficient value in the original sample between ECRM and repurchase intention is 0.204. This Hypothesis is also supported by significant testing on the $\mathrm{t}$ statistic and $\mathrm{p}$-value. The Obtained $\mathrm{t}$ statistic is 2.807 ( $\mathrm{t}$ statistic > 1.96) and the obtained p-value is 0.005 (p-value < 0.05 ). It can be concluded from the acquired data that $\mathrm{H} 3$ is accepted, and ECRM has a Positive Influence on repurchase intention. 


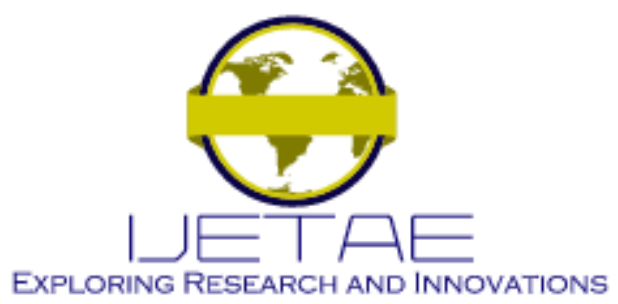

International Journal of Emerging Technology and Advanced Engineering

Website: www.ijetae.com (E-ISSN 2250-2459, Scopus Indexed, ISO 9001:2008 Certified Journal, Volume 11, Issue 12, December 2021)

H4: Customer Satisfaction has a positive effect on repurchase intention. The fourth Hypothesis states that customer satisfaction has a positive influence on repurchase intention. The parameter coefficient value in the original sample between customer satisfaction and repurchase intention is 0.290. This Hypothesis is also supported by significant testing on the $\mathrm{t}$ statistic and $\mathrm{p}$-value. The obtained $\mathrm{t}$ statistic is 3,433 (t statistic > 1.96) and the obtained p-value is 0.001 ( $\mathrm{p}$-value $<0.05$ ). It can be concluded from the acquired data that $\mathrm{H} 4$ is accepted, and customer satisfaction has a positive influence on repurchase intention.

H5: Customer Trust has a positive influence on Repurchase Intention. The fifth Hypothesis states that customer trust has a positive influence on repurchase intention. The parameter coefficient value in the original sample between customer trust and repurchase intention is 0.219. This Hypothesis is also supported by significant testing on the $t$ statistic and p-value. The obtained t statistic is 2,692 (t statistic > 1.96) and the obtained p-value is 0.007 (p-value $<0.05)$. It can be concluded from the acquired data that $\mathrm{H} 5$ is accepted, and customer trust has a significant positive influence on repurchase intention.

H6: ECRM has a positive influence on Repurchase Intention through customer satisfaction mediation, The sixth Hypothesis states that ECRM has a positive influence on repurchase intention, which is mediated by the customer trust variable. The parameter coefficient value in the original sample between customer trust and repurchase intention is 0.219. This Hypothesis is also supported by significant testing on the $\mathrm{t}$ statistic and $\mathrm{p}$-value. The obtained $\mathrm{t}$ statistic is 2,573 ( $\mathrm{t}$ statistic $>1.96$ ) and the obtained p-value is 0.010 ( $\mathrm{p}$-value $<0.05$ ). It can be concluded from the acquired data that H6 is accepted and ECRM mediated by customer satisfaction has a positive influence on repurchase intention.

H7: ECRM has a positive influence on Repurchase Intention through customer trust mediation, The seventh Hypothesis states that ECRM has a positive influence on repurchase intention by mediating the customer trust variable. The parameter coefficient value in the original sample between customer trust and repurchase intention is 0.194. This Hypothesis is also supported by significant testing on the $\mathrm{t}$ statistic and $\mathrm{p}$-value. The obtained $\mathrm{t}$ statistic is 3.364 ( $\mathrm{t}$ statistic > 1.96) and the obtained p-value is 0.001 (p-value <0.05).
It can be concluded from the acquired data that $\mathrm{H} 7$ is accepted and ECRM mediated with customer trust has a positive influence on repurchase intention

\section{CONClusion AND SugGestion}

ECRM has a positive and significant influence on customer satisfaction. This study proves that direct results from ECRM provide satisfaction to customers who use E-Commerce ECRM has a positive and significant influence on customer trust. This study proves that the direct result from ECRM is a factor that determines Customers' belief in a company.

ECRM has a positive and significant effect on direct repurchase intention. This study proves that the results of direct practice from ECRM could make the customers continue using the product. Customer satisfaction has a significant and positive effect on repurchase intention. This study proves that customer satisfaction is a crucial factor to increase Customers' repurchase intention.

It can be concluded that customer trust has a significant and positive effect on repurchase intention. This study proves that customer trust is an essential factor for an E-commerce to compete in the competitive digital world.

In addition to direct influence, indirect analysis is also conducted between exogenous and endogenous variables. It proves that ECRM has a positive and significant direct and indirect effect on repurchase intention. It can be concluded that an ECRM practice would encourage the customers to keep buying the product, and customer satisfaction would result in a loyal customer for a company.

This study also proves that ECRM has a positive and significant direct and indirect influence on repurchase intention through the Customer's trust. It can be concluded that an E-Commerce system that the customers can trust would make the customers use the E-Commerce system again in the future.

\section{REFERENCES}

[1] N. A. B. Ismail and H. B. Hussin, The effect of E-CRM features on customers satisfaction for airline E-ticket services in Malaysia, Proceedings - 6th International Conference on Information and Communication Technology for the Muslim World, ICT4M 2016, pp. 336-343. doi: 10.1109/ICT4M.2016.67, 2017.

[2] J. Kandampully, Z. Tingting Christina and A. Bilgihan, Customer loyalty: A review and future directions with a special focus on the hospitality industry, International Journal of Contemporary Hospitality Management, vol. 27, no. 3, pp. 379-414. doi: 10.1108/IJCHM-03-2014-0151, 2015. 


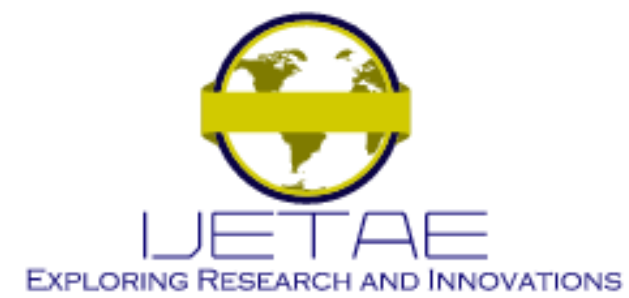

International Journal of Emerging Technology and Advanced Engineering

Website: www.ijetae.com (E-ISSN 2250-2459, Scopus Indexed, ISO 9001:2008 Certified Journal, Volume 11, Issue 12, December 2021)

[3] E. Abu-Shanab and L. Anagreh, Impact of electronic customer relationship management in banking sector, International Journal of Electronic Customer Relationship Management, vol.9, no.4, pp. 254-271. doi: 10.1504/IJECRM.2015.074196, 2015.

[4] C Hendriyani Analysis building customer engagement through e-CRM in the era of digital banking in Indonesia, International Journal of Economy Policy in Emerging Economies, vol. 11, no. 5, pp. 479-486, 2018

[5] A. Bhattacherjee, An empirical analysis of the antecedents of electronic commerce service continuance, Decision Support Systems, vol.32, no.2, pp. 201-214. doi: 10.1016/S0167-9236(01)00111-7, 2001.

[6] K. Adomaviciute, G. Bzikadze, J. Cherian, and S. Urbonavicius, Cause-related marketing as a commercially and socially oriented activity: What factors influence and moderate the purchasing intentions?, Engineering Economics, vol.27, no.5, pp. 578-585. doi: 10.5755/j01.ee.27.5.15166, 2016.
[7] M. Kos, M. Kukar-kinney, and S. Vegelj, An investigation of customer satisfaction with low-cost and full-service airline companies', Journal of Business Research, (November 2016), pp. 0-1. doi: 10.1016/j.jbusres.2017.05.015, 2017.

[8] P. M. Abdullah, Living in the world that is fit for habitation : CCI's ecumenical and religious relationships, 2005.

[9] S. Vergura, G. Acciani, V. Amoruso, and G. Patrono, Descriptive and Inferential Statistics for Supervising and Monitoring the Operation of PV Plants, IEEE Transactions on Industrial Electronics, vol.56, no.11, pp. 4456-4464, 2009.

[10] Z. Awang, VALIDATING THE MEASUREMENT MODEL: CFA The measurement model of a latent construct', SEM Made Simple, pp. 54-74, 2015

[11] J. F. Hair Jr, G. Thomas M. Hult, C. Ringle, and M. Sarstedt, A Primer on Partial Least Squares Structural Equation Modeling (PLS-SEM), Sage, Thousands Oak, 2016. 